\title{
An intern's world?
}

Written by: Caroline Fouvet

Last update: 2 December 2019

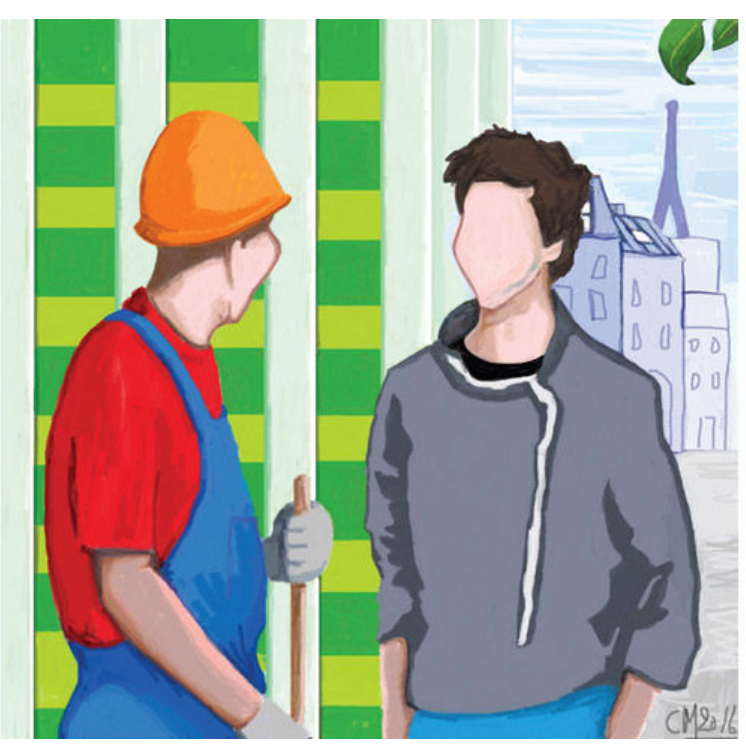

In 2015 the story of an unpaid intern working for an international organisation in Geneva who slept in a tent because he could not afford the rent made the headlines and sparked discussion on social media. Nowadays, internships-also known as job placements and stages-are almost an obligatory step on the way to finding a decent job, and are a requirement in some higher education courses. It is also a well-known fact that most interns are ready to undergo some financial hardship as a price for gaining good professional experience and adding value to their curriculum vitae in what has become a highly competitive global labour market. This is just as well, for although some job placements offer small stipends to keep the wolf from the door, too many internships offer no money at all. In France, for instance, internships of two to six months pay just over $€ 550$ per month, but under two months no pay is required.

Given this characterisation, it may come as a surprise to read a ranking recently released by Glassdoor, a job hunting website, which shows that in some sectors, such as finance and high tech, being an intern can pay as much if not more than regular jobs. In France, for instance, the Boston Consulting Group, ranked first among the companies that pay their interns the most, offered $€ 2200$ a month, followed by Google with $€ 2000$.

In the US, more dazzling sums are paid, especially in the tech industry. Dan Zhang, a sixth-year computer engineering doctoral student at the University of Texas in Austin collected data from coding interns at 100 tech and non tech firms, 
which show interns earning between US\$6-8 500 a month in tech firms such Dropbox, Facebook and Microsoft. The data included the base salary and add-ons, such as benefits for housing, travel, and food.

And so, you might say? It sure beats living in a tent in Geneva. Shouldn't we be delighted that some young interns fare so well in a particularly demanding job market? As Dan Zhang argues, these internships provide talented people with an opportunity to apply their academic knowledge directly within a professional setting. Ben Lyons, who is co-director of Intern Aware, a UK-based campaign in favour of paid internships, also believes that compensation enables tech firms to attract people based on merit, while helping firms reduce costs and gain flexibility.

Is that what internships are really for? And is that not what the real job market is for? Should interns expect a large salary or just fair compensation to help them complete their education? And what about the armies of interns who also perform real jobs but whose monthly pay is by no means comparable to the four-digit sums high tech interns receive? And what about the many real employees who are likely paid less than interns?

This paradox shows that, although the number of internship positions is soaring, the defining lines between an interns' status and that of a worker risk becoming blurred, to the detriment of the status of work itself, and of education too. It

the defining lines between an interns' status and that of a worker risk becoming blurred appears that the growing importance of internships as a means to stand out in a tremendously competitive job market is fostering new inequalities and creating distortions regarding people's status and skills.

Surely, an internship should remain a training experience, designed to contribute to a student's education by enhancing their professional skills, while increasing the odds of their obtaining a proper job upon completion. An intern and a fulltime employee constitute a complementary force in a company to which they should contribute, but at different levels.

The impressive salaries earned by some interns should not overshadow the tough situation many unpaid interns find themselves in as they struggle to make ends meet in expensive cities like Geneva, London and Paris. A clearer legislation or agreed framework at the international level would be valuable to help define the interns' status, work and entitlements, and to improve their situation. This also demands commitment, vigilance and oversight by governments and higher educational establishments, and more awareness among interns about their rights. 
Internships offer a wonderful opportunity for students and firms alike to learn and progress, and to prepare for the future of work. Underpaying or overpaying interns simply muddies this vision.

Caroline Fouvet was an OECD intern in 2015.

COECD Observer No 305 Q1 2016

For more on French internship rates, see https://www.service-public.fr/

\%20professionnels-entreprises/vosdroits/F32131

\section{References}

Lyons, Ben (2015), "Interns are workers, too", in OECD Yearbook 2013 http:// oe.cd/1gn

Smith, Jack (2014), "The master list of tech internship salaries revealed" in Observer.com, February http://observer.com/2014/12/the-master-list-of-techinternship-salaries-revealed/

Weissmann, Jordan (2014), "An even longer list of tech internship salaries that will make your eyes water", in Slate.com, December http://www.slate.com/ blogs/moneybox/2014/12/05/

tech_internship_salaries_an_even_longer_list_that_will_make_your_eyes_wate r.html 